\title{
Biodiversity assessment of African locust bean (Parkia biglobosa) accessions from Savanna and Forest zones of Nigeria as revealed by seed storage proteins and RAPD markers
}

\author{
Pamela E Akin-Idowu *,a , Ayodeji O Aduloju ${ }^{\mathrm{a}}$, Omolara I Akinyoola ${ }^{\mathrm{a}}$, Dorcas O Ibitoye ${ }^{\mathrm{b}}$, \\ Uterdzua Orkpeh $^{\mathrm{b}}$, Usifo G Adebo ${ }^{\mathrm{a}, \mathrm{c}}$ and Yemisi O Olagunju ${ }^{\mathrm{a}}$ \\ ${ }^{a}$ Biotechnology Unit, National Horticultural Research Institute, P.M.B. 5432, Jericho Reservation Area, Idi-Ishin, Ibadan, \\ Nigeria \\ ${ }^{b}$ Genetic Resources Unit, National Horticultural Research Institute, P.M.B. 5432, Jericho Reservation Area, Idi-Ishin, \\ Ibadan, Nigeria \\ ${ }^{c}$ School of Agriculture and Food, Faculty of Veterinary and Agricultural Sciences, The University of Melbourne, Melbourne, \\ Australia
}

\begin{abstract}
Understanding the level and distribution of genetic diversity in African locust bean (Parkia biglobosa) would strengthen breeding and conservation programmes towards domestication and sustainable use of this species. Sixteen accessions of $P$. biglobosa were assessed for variability based on seed morphology, seed protein and DNA profiling. Significant variation in seed characteristics were observed across locations. Seed protein profiling by SDS-PAGE revealed homogeneity as most bands were found common in all accessions, indicating that the protein profiles are highly conserved. Protein profiling separated the 16 accessions into four major clusters at 0.93 similarity coefficient. Most accessions grouping into Cluster 1 had a similarity coefficient of close to $100 \%$ and were from the Derived Savanna suggesting the presence of duplicates. Accessions NH/2016/P14, NH/2016/P03 and NH/2016/P04 grouped into clusters II, III and IV; respectively. Sixteen RAPD markers generated a total of 256 bands of which $63.67 \%$ were polymorphic. Gene diversity ranged from 0.41 to 0.93 and Polymorphic Information Content (PIC) from 0.39 to 0.93 . The RAPD-based dendrogram separated accessions into six groups at 0.68 similarity coefficient. Based on a polymorphic seed storage protein marker a genetically distinct accession NH/2016/P04 could be exploited for breeding purposes. The homogeneity of alleles and narrow genetic base as revealed by RAPD and SDSPAGE analyses suggests possible loss of intraspecific genetic diversity. Thus, intensification of germplasm collections across the different agroecological zones and characterization using specific markers will give a better understanding of diversity of $P$. biglobosa in order to enhance selection towards conservation, breeding and sustainable utilization.
\end{abstract}

Keywords: African locust bean, genetic diversity, agroecological zone, RAPD, SDS-PAGE, Parkia biglobosa

Citation: Akin-Idowu, P. E., Aduloju, A. O., Akinyoola, O. I., Ibitoye, D. O., Orkpeh, U., Adebo, U. G., Olagunju, Y. O. (2021). Biodiversity assessment of African locust bean (Parkia biglobosa) accessions from Savanna and Forest zones of Nigeria as revealed by seed storage proteins and RAPD markers. Genetic Resources 2 (3), 36-50. doi: 10.46265/genresj.OBVW6791.

(C) Copyright 2021 the Authors.

This is an open access article distributed under the terms of the Creative Commons Attribution License (CC BY 4.0), which permits unrestricted use, distribution, and reproduction in any medium, provided the original author and source are

credited.

${ }^{*}$ Corresponding author: Pamela E Akin-Idowu (elohoidowu@hotmail.com)

\section{Introduction}

In Sub-Saharan Africa several indigenous agroforestry systems exist containing woody species known as multipurpose trees. Africa locust bean [Parkia biglobosa (Jacq.) R. Br. ex G. Don] is a well-known indigenous 
agroforestry fruit tree species belonging to the subfamily Mimosoideae and family Fabaceae (Amusa et al, 2014; Houndonougbo et al, 2020). The species grows in multiple climatic zones and is widely distributed from Senegal and Guinea in West Africa to Uganda in Central Africa (Lompo et al, 2018). Parkia biglobosa is maintained in the parklands of Africa for nontimber forest foods (Houndonougbo et al, 2020; Leakey, 2012; Okoye et al, 2014). P. biglobosa is a valuable resource for the livelihoods of local people in Sub-Saharan Africa because of its multipurpose function as a source of food, nutrition, medicine and income (Matig et al, 2002; Nikiema, 2005; Awodoyin et al, 2015; Sankhon et al, 2014; Shao, 2002; Sina and Traore, 2002; Teklehaimanot, 2004). The fruit pulp and seeds are both suitable for human consumption. The mealy pulp from the species' fruits is a major source of energy and nutrients including carbohydrates, proteins, lipids, carotenoids, vitamins A, B, C, and oligoelements (Nyadanu et al, 2017). The seeds are an important source of plant protein and essential amino acids among rural communities who often have limited access to animal proteins due to high cost (Akin-Idowu et al, 2018; Alabi et al, 2005) and are also rich in energy value, saccharose, vitamin C, lipids, carbohydrates (Orwa et al, 2010) and bioactive components such as phenolic compounds which may contribute in health promoting properties (Dedehou et al, 2016; Okoye et al, 2014). P. biglobosa seeds are fermented to make a food condiment called Dawadawa (Iru) which is rich in dietary protein and serves as an important substitute for animal protein (Lamien et al, 2011; Nyadanu et al, 2017). The leaves, bark, roots and flowers are also used in the treatment of many diseases such as hypertension, wound healing and malaria (Dedehou et al, 2016; Ouedraogo, 1995).

In spite of the importance of this species in traditional agriculture, regular cultivation of the fruit tree has rarely gone beyond conservation of natural stands in situ (Hopkins, 1983; Oni et al, 1998). Several studies on $P$. biglobosa population structure have shown low regeneration rates and ageing of the stands which may lead to extinction (Padakale et al, 2015; Ræbild et al, 2012a). Overexploitation, late fruitification for most progenies and climate change are some of the factors suggested to explain the phenomenon (Boffa, 1999; Kwon-Ndung et al, 2009; Teklehaimanot, 2004). Improved tree management practices for $P$. biglobosa, such as establishment of new trees or protection of natural regeneration are currently not sufficiently promoted (Ræbild et al, 2012b). Thus, African locust bean remains undomesticated despite increasing demand for its use.

The conservation and sustainable use of genetic resources are critical to maintain tree resource availability, especially in the face of significant environmental changes, erosion of cultural heritages and declining cultivation and production activities of neglected indigenous species leading to genetic resources being threatened. The process of plant domestication and conservation requires characterization of genetic resources for identification of cultivars and effective utilization of germplasm.

Genome size variation has been identified as an associate of evolutionary divergence (Dobes et al, 2019). Variation in genome size and chromosome number becomes taxonomically significant if associated with some degrees of morphological and ecological differentiation (Murray, 2005). Sina (2006) studied genetic diversity among populations of $P$. biglobosa species in Burkina Faso using enzyme electrophoresis. Dobes et al (2019) tested for linkage of relative genome size variation with geography, leaf morphology and population genetic variation in 58 individuals from 15 populations covering most of the distribution of $P$. biglobosa species in Burkina Faso. Most of the variation was found within populations and there was no evidence from the karyological data for structured intraspecific taxonomic heterogeneity (Dobes et al, 2019).

In Nigeria, genetic diversity of $P$. biglobosa accessions have been evaluated based on morphological characterization of trees (Gbadamosi et al, 2005; Okunlola et al, 2011) and seedlings (Adesoye et al, 2013). However, these characters are known to be more influenced by the environment. Uyoh et al (2011) reported variation in banding pattern of proteins obtained from leaf samples of three accessions of P. biglobosa collected from locations within Cross River State, Nigeria. Adesoye and Apo (2015) reported low levels of genetic diversity when 34 accessions of $P$. biglobosa were screened using seed protein electrophoresis. Owing to the limited information on genetic variation and relationship of $P$. biglobosa accessions in Nigeria, characterization using a combination of morphological, biochemical and molecular markers is essential for species identification and genetic variability establishment. This will facilitate the domestication, conservation and management of its genetic resources towards sustainable use.

Morphological characterization has been used to reveal phylogenetic relationships among crop populations, but this has its limitations as it is influenced by environmental factors (Ferreira, 2006). Selection, according to genetic variability using biochemical and molecular markers, has proved advantageous compared with the use of phenotypic markers (Alghamdi et al, 2019).

Biochemical analysis, particularly electrophoresis of seed proteins has been effective in studying genetic diversity at intraspecific levels in several legumes including soybean and chickpea (Durán et al, 2005; Signor et al, 2005; Malik et al, 2009; Sammour et al, 2007a,b) and for cultivar identification (Krochko and Bewley, 2000; Mustafa and El-Kholy, 2008).

The use of polyacrylamide gel electrophoresis (PAGE) in fractionating seed proteins and evaluating genetic diversity among accessions of several legume species including groundnut, African yam bean, grass pea, buckwheat, bambara groundnut and underground vetches 
has also proven effective (la Rosa and González, 2010; Javaid et al, 2004; Machuka, 2001; Przybylska et al, 2000).

Molecular markers are known as one of the best approaches to study genetic material as well as to assess genetic variation in crop gene pools (Badr, 2008; Mondini et al, 2009; Wang et al, 2016). A number of PCR based molecular markers such as Random Amplified Polymorphic DNA (RAPD), Inter Simple Sequence Repeats (ISSR) and Amplified Fragment Length Polymporhism (AFLP) have been used to assess genetic variability and cultivar identification in soybean (Barakat, 2004; Baránek et al, 2002; Chowdhury et al, 2001; El-Kholy, 2013) and other plant populations (Hoque and Hasan, 2012; Lin et al, 2009). RAPD is often used successfully to assess genetic diversity among species as it is fast, less technical and expensive and may reveal dominant molecular marker of good potential (Badr et al, 2012; Prasanthi et al, 2012).

This study aimed to estimate the genetic diversity of P. biglobosa accessions across different agro-ecological zones in Nigeria using SDS-PAGE and RAPD markers.

\section{Materials and Methods}

\section{Plant material and morphological description}

Seeds of $P$. biglobosa were obtained from 16 locations across seven states in Nigeria (Figure 1). Thirteen of the sixteen accessions studied were collected from locations in the Derived Savanna agroecological zone (AEZ); two were collected from the Guinea Savanna and one from Humid Forest (Figure 1, Table 1). The sampling of $P$. biglobosa accessions was not conducted systematically across all AEZs because the species is reported to be widely adapted and naturally distributed throughout the varied savannas of Sub-Saharan Africa (Lompo et al, 2016). The seed morphological characteristics of each collected accession, including seed shape, seed coat color and seed coat texture were observed. One hundred (100) seed weight in grams of each accession was also recorded.

\section{Seed preparation and total protein extraction}

Dried seeds were milled into flour and defatted with $\mathrm{n}$ hexane at a flour:hexane ratio of $1: 10(\mathrm{w} / \mathrm{v})$ prior to protein extraction (de la Rosa et al, 1992).

Seed total protein extraction was carried out by suspending defatted flour samples $(100 \mathrm{mg})$ in $2.0 \mathrm{~mL}$ of pre-chilled Tris buffer $50 \mathrm{mM}$ Tris-HCl, $\mathrm{pH}$ 7.6, $1 \mathrm{mM}$ DDT, $150 \mathrm{mM} \mathrm{NaCl}$ and $1 \mathrm{mM}$ EDTA for $2 \mathrm{~h}$ at room temperature according to the method of Zarkadas et al (2007). The resulting homogenates were centrifuged at $10,000 \mathrm{~g}$ for $20 \mathrm{~min}$ and supernatants were stored at $-20^{\circ} \mathrm{C}$ until used.

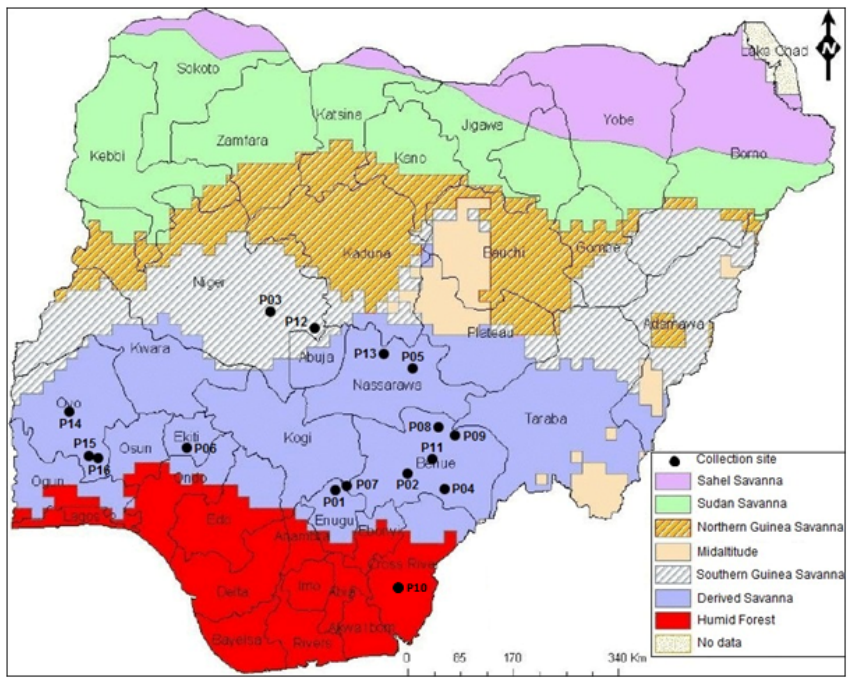

Figure 1. Map of Nigeria showing agroecological zones of the collection sites of sixteen Parkia biglobosa accessions

\section{One dimensional SDS-PAGE}

Sodium dodecyl sulfate-polyacrylamide gel electrophoresis (SDS-PAGE) was performed according to the procedure of Laemmli (1970). Protein extracts were diluted in a sample buffer that contained 60 $\mathrm{mM}$ Tris- $\mathrm{HCl}(\mathrm{pH}$ 6.8), $2 \% \mathrm{w} / \mathrm{v}$ SDS, $3.33 \% \mathrm{v} / \mathrm{v} \beta$ mercaptoethanol, $10 \%$ glycerol and $0.05 \%$ of bromophenol blue. The samples were heated at $98^{\circ} \mathrm{C}$ for $5 \mathrm{~min}$ before loading onto a vertical slab gel (Mini-PROTEAN II Electrophoresis Cell) using a 4\% (w/v) stacking and $12 \%$ gradient separating (acrylamide/bis acrylamide) gel containing $0.1 \%$ SDS. The separating polypeptide bands were calibrated using a protein molecular weight marker which ranged from 11 to $130 \mathrm{kDa}$. Electrophoresis was done at $125 \mathrm{~V}$ for about $2 \mathrm{~h}$. At the end of the run, the gels were stained with Coomassie brilliant blue R-250 (SigmaAldrich) in methanol/water/acetic acid (40:50:10) and destained in a solution containing methanol/water/acetic acid (50:40:10).

\section{Genomic DNA extraction, RAPD amplification and electrophoresis}

For the genetic analysis, ten viable seeds of each of the sixteen accessions of P. biglobosa collected from the different locations were grown in a greenhouse. Prior to sowing, the seeds were immersed in concentrated sulphuric acid $\left(\mathrm{H}_{2} \mathrm{SO}_{4}\right)$ for 15 minutes to break seed dormancy, rinsed thoroughly in running water and air dried at room temperature. Total genomic DNA was extracted from young leaves of P. biglobosa accessions. About $0.2 \mathrm{~g}$ of a composite of 5 samples per accession was ground in extraction buffer following the cetyltrimethyl ammonium bromide (CTAB) method of Dellaporta et al (1983).

The DNA quality was evaluated using $1 \%$ agarose gel electrophoresis with known concentrations of undigested lambda DNA (Sigma, St Louis, MO, USA). Quantification of DNA was done using a spectrophotometer 
Table 1. Parkia biglobosa accessions used in this study and collection sites.

\begin{tabular}{|c|c|c|c|c|}
\hline \multirow{2}{*}{ Accession code } & \multirow{2}{*}{ Collection site } & \multirow{2}{*}{ Agroecological Zone } & \multicolumn{2}{|c|}{ Geographical Coordinates (DD) } \\
\hline & & & Longitude & Latitude \\
\hline $\mathrm{NH} / 2016 / \mathrm{P} 01$ & Obollo-Afor, Enugu State & Derived Savanna & $6.9153^{\circ} \mathrm{N}$ & $7.5139^{\circ} \mathrm{E}$ \\
\hline NH/2016/P02 & Oju, Benue State & Derived Savanna & $7.0383^{\circ} \mathrm{N}$ & $8.3451^{\circ} \mathrm{E}$ \\
\hline $\mathrm{NH} / 2016 / \mathrm{P} 03$ & Minna, Niger State & Guinea Savanna & $9.5836^{\circ} \mathrm{N}$ & $6.5463^{\circ} \mathrm{E}$ \\
\hline $\mathrm{NH} / 2016 / \mathrm{P0} 4$ & Vandeikya, Benue State & Derived Savanna & $6.7835^{\circ} \mathrm{N}$ & $9.0695^{\circ} \mathrm{E}$ \\
\hline NH/2016/P05 & Agyaragu, Nasarawa State & Derived Savanna & $8.3471^{\circ} \mathrm{N}$ & $8.5679^{\circ} \mathrm{E}$ \\
\hline NH/2016/P06 & Ikere, Ekiti State & Derived Savanna & $7.5000^{\circ} \mathrm{N}$ & $5.2333^{\circ} \mathrm{E}$ \\
\hline NH/2016/P07 & Orokam, Benue State & Derived Savanna & $6.9786^{\circ} \mathrm{N}$ & $7.5572^{\circ} \mathrm{E}$ \\
\hline $\mathrm{NH} / 2016 / \mathrm{P} 08$ & Gbajimba, Benue State & Derived Savanna & $7.8197^{\circ} \mathrm{N}$ & $8.8587^{\circ} \mathrm{E}$ \\
\hline NH/2016/P09 & Kwatan-Sule, Benue State & Derived Savanna & $7.8112^{\circ} \mathrm{N}$ & $9.2429^{\circ} \mathrm{E}$ \\
\hline $\mathrm{NH} / 2016 / \mathrm{P} 10$ & Ogoja, Cross River State & Humid Forest & $6.6548^{\circ} \mathrm{N}$ & $8.7977^{\circ} \mathrm{E}$ \\
\hline $\mathrm{NH} / 2016 / \mathrm{P} 11$ & Mbatiav, Gboko, Benue State & Derived Savanna & $7.2788^{\circ} \mathrm{N}$ & $8.7953^{\circ} \mathrm{E}$ \\
\hline $\mathrm{NH} / 2016 / \mathrm{P} 12$ & Suleja, Niger State & Guinea Savanna & $9.2003^{\circ} \mathrm{N}$ & $7.1723^{\circ} \mathrm{E}$ \\
\hline $\mathrm{NH} / 2016 / \mathrm{P} 13$ & Garaku, Nassarawa State & Derived Savanna & $8.8444^{\circ} \mathrm{N}$ & $8.1311^{\circ} \mathrm{E}$ \\
\hline $\mathrm{NH} / 2016 / \mathrm{P} 14$ & Iseyin, Oyo State & Derived Savanna & $7.9765^{\circ} \mathrm{N}$ & $3.5914^{\circ} \mathrm{E}$ \\
\hline $\mathrm{NH} / 2016 / \mathrm{P} 15$ & NIHORT, Ibadan, Oyo State & Derived Savanna & $7.4052^{\circ} \mathrm{N}$ & $3.8499^{\circ} \mathrm{E}$ \\
\hline NH/2016/P16 & Oje Market, Ibadan, Oyo State & Derived Savanna & $7.3891^{\circ} \mathrm{N}$ & $3.9092^{\circ} \mathrm{E}$ \\
\hline
\end{tabular}

(Beckman Coulter DU530) at $260 \mathrm{~nm}$. Extracts were diluted to obtain DNA concentrations of $25 \mathrm{ng} / \mu \mathrm{l}$. To generate DNA profiles, 40 decamer oligonucleotide DNA primers were initially screened for polymorphisms and only 16 which were polymorphic were used in the PCR reactions (Table 2).

To ensure reproducibility of RAPD markers, RAPDPCR amplification was performed in triplicate for each primer and accession. The PCR reaction contained the following reagents with the final concentrations: $1 \mathrm{x}$ PCR buffer, dNTPs (0.2 mM), $\mathrm{MgCl}_{2}(2.0 \mathrm{mM})$, primer (25 pmol), template DNA $(25 \mathrm{ng} / \mu \mathrm{l})$, Taq polymerase (1.25 $\mathrm{U})$ and nuclease-free water to $50 \mu \mathrm{l}$. Amplification was carried out in a 2400 Perkin Elmer Gene Amp PCR thermo-cycler as follows: pre-denaturation for $3 \mathrm{~min}$ at $94^{\circ} \mathrm{C}$; then 40 cycles each consisting of a denaturation step for $1 \mathrm{~min}$ at $94^{\circ} \mathrm{C}$; an annealing step for $1 \mathrm{~min}$ at $36^{\circ} \mathrm{C}$; an extension step for $90 \mathrm{sec}$ at $72^{\circ} \mathrm{C}$. Amplification was terminated by a final extension of $7 \mathrm{~min}$ at $72^{\circ} \mathrm{C}$. PCR products were electrophoresed on a $1.5 \%(\mathrm{w} / \mathrm{v})$ agarose gel in 1X Tris/Borate/EDTA (TBE) buffer at 100 volts for $2 \mathrm{~h}$ and visualized under UV light after staining with ethidium bromide.

\section{Data analysis}

Data on 100-seed weight of all accessions were subjected to ANOVA and means were separated using Duncan's multiple range tests $(\mathrm{p} \leq 0.05)$. Distribution frequencies of the qualitative traits were calculated using Microsoft Excel 2010. The protein bands and RAPD amplified DNA fragments were scored qualitatively, whereby (0) stands for the absence and (1) stands for the presence of bands in the profile of each accession. All values were pooled together to generate a binary data matrix, which was analyzed using the Numerical Taxonomy and Multivariate Analysis System (Rohlf, 2002). Genetic relationship among accessions was evaluated based on Jaccard's similarity index (Jaccard, 1908). Dendrograms were generated by using the Unweighted Pair Group Method with Arithmetic Mean (UPGMA). Analysis of genetic diversity (GD) was calculated according to the method of Nei (1987). Polymorphic information content (PIC) for each primer was determined from allele frequencies (Nei and Li, 1979).

\section{Results and Discussion}

\section{Variation in seed morphology}

Improvement of the quality of indigenous fruit trees across Sub-Saharan Africa involves assessment of fruit/seed traits; this has shown significant variation both among and within provenances and has enhanced selection in breeding programmes (Ræbild et al, 2012a). In this study, significant differences $(\mathrm{p} \leq 0.05)$ were observed in the 100-seed weight of $P$. biglobosa collected from 16 different locations (Table 3 ), which ranged from $17.93 \mathrm{~g}(\mathrm{NH} / 2016 / \mathrm{P} 09)$ to $26.11 \mathrm{~g}(\mathrm{NH} / 2016 / \mathrm{P} 05)$. The highest 100-seed weight was recorded for accession NH/2016/P05 collected from Agyaragu, Nassarawa State; this was significantly $(\mathrm{p} \leq 0.05)$ higher than that of all other accessions. The lowest 100-seed weight was recorded for NH/2016/P09 collected from KwatanSule, Benue State. The mean 100-seed weight (21.46g) of all accessions of P. biglobosa collected from the Derived Savanna zone was higher than the mean 100seed weight collected from the Guinea Savanna and Humid Forest (Figure 2a). This variation in seed weight can be attributed to a wide range of factors such as environment (soil, climate), anthropogenic activities and phenotypic plasticity, thus promoting the presence of ecotypes. 
Table 2. List of primers used and RAPD polymorphisms among Parkia biglobosa accessions.

\begin{tabular}{llllll}
\hline Primer & Sequence 5' to 3' & $\begin{array}{l}\text { Major allele } \\
\text { frequency }\end{array}$ & $\begin{array}{l}\text { Allele } \\
\text { number }\end{array}$ & $\begin{array}{l}\text { Gene } \\
\text { Diversity }\end{array}$ & $\begin{array}{l}\text { Polymorphic } \\
\text { Information content } \\
\text { (PIC) }\end{array}$ \\
\hline OPB10 & CTGCTGGGAC & 0.13 & 15 & 0.93 & 0.93 \\
OPT07 & GGCAGGCTGT & 0.13 & 14 & 0.92 & 0.92 \\
OPB04 & GGACTGGAGT & 0.13 & 14 & 0.92 & 0.92 \\
OPT12 & GGGTGTGTAG & 0.13 & 14 & 0.92 & 0.92 \\
OPT08 & AACGGCGACA & 0.13 & 13 & 0.91 & 0.91 \\
OPT06 & CAAGGGCAGA & 0.19 & 13 & 0.91 & 0.90 \\
OPH07 & CTGCATCGTG & 0.19 & 12 & 0.90 & 0.89 \\
OPB08 & GTCCACACGG & 0.19 & 9 & 0.87 & 0.85 \\
OPT20 & GACCAATGCC & 0.25 & 9 & 0.84 & 0.82 \\
OPH06 & ACGCATCGCA & 0.38 & 9 & 0.80 & 0.78 \\
OPT09 & CACCCCTGAG & 0.38 & 9 & 0.80 & 0.78 \\
OPT10 & CCTTCGGAAG & 0.44 & 10 & 0.77 & 0.76 \\
OPT01 & GGGCCACTCA & 0.44 & 7 & 0.74 & 0.71 \\
OPT16 & GGTGAACGCT & 0.56 & 6 & 0.64 & 0.61 \\
OPB05 & TGCGCCCTTC & 0.56 & 5 & 0.63 & 0.59 \\
OPT05 & GGGTTTGGCA & 0.75 & 4 & 0.41 & 0.39 \\
\hline Mean & & 0.31 & 10 & 0.81 & 0.79 \\
Total & & & & \\
\hline
\end{tabular}

Leakey (2017) reported that fruit and/or kernel size was greater in more humid sites for Adansonia digitata and Vitellaria paradoxa; but greater in drier sites for Balanite aegyptiaca. Also, results from tests of B. aegyptiaca and Prosopis Africana indicated that provenances from drier sites had significantly better aboveground growth than provenances from more humid sites (Leakey, 2017). It is recommended that fruit trees germplasm should be collected in drier sites for future plantings in parklands, especially as this germplasm appears to be better adapted to dry conditions (Leakey, 2017).

The seeds of $P$. biglobos $a$ accessions collected from the different locations in this study had distinct morphology and exhibited variation for seed shape, seed coat colour and seed coat texture (Table 3). Seeds of the sixteen $P$. biglobosa accessions were predominantly round oval in shape, black in colour with smooth seed coat and were mostly obtained from the Derived Savanna zone (Figure 2B, C, D). Seeds collected from the two sites in Guinea Savanna differed in shape and texture as seeds from one site were flat oval, black and smooth (NH/2016/P03) (Figure 3B); while seeds from the other site were round oval, black and rough (NH/2016/P12) (Figure 3C). Seeds collected from the same agroecological zone (Derived Savanna) exhibited distinct variation in colour and texture, NH/2016/P15 seeds were flat oval, brown and smooth (Figure 3E); while seeds of NH/2016/P04 were flat oval, black and wrinkled.

The morphological variation may be due to gene flow across regions because of seed dispersal since $P$. biglobosa is an open pollinated tree crop having main pollinators such as bat, honeybees, rodents and humans (Lassen et al, 2012; Lassen, 2016; Lompo et al, 2017). This variation offers great potential for future selection and domestication.

Lack of a clear association between genome size and morphological, geographical, or ecological patterns of differentiation has been reported for two species of Artemisia (Asteraceae) (Dobes et al, 2019; de Xaxars et al, 2016).

\section{Seed storage protein analysis}

Seed storage protein profiling has been used as an effective tool for varietal identification and determination of phylogenetic relationship in several plant species populations (Emre, 2009; Hameed et al, 2012; Machuka, 2001).

In this study, the SDS-PAGE profile of sixteen accessions of $P$. biglobosa showed similar electrophoretic patterns with respect to the number of protein bands and their band intensities (Figure 4). The uniformity in the protein band profiles of all sixteen accessions suggests a low level of genetic diversity, which also corroborates earlier studies on P. biglobosa using seed protein electrophoresis (Adesoye and Apo, 2015).

Occurrence of a narrow genetic base from the accessions of $P$. biglobosa would suggest that they resulted not only from a common gene pool, but also from the outcrossing nature of the species over a long time, leading to a low level of inter-population diversity. Low variation was observed in thirteen mungbean varieties using SDS-PAGE (Hameed et al, 2012) and also in genetic diversity assessment of groundnut using SDSPAGE (Javaid et al, 2004). 
Table 3. Seed characteristics of Parkia biglobosa accessions used in this study. Values are mean \pm Standard Error. Means within the same column with different letters are significantly $(\mathrm{p} \leq 0.05)$ different.

\begin{tabular}{|c|c|c|c|c|}
\hline Accession code & $\begin{array}{l}\text { Weight of } 100 \text { seeds } \\
\text { (g) Mean } \pm \text { SE }\end{array}$ & Shape & Colour & Seed coat texture \\
\hline NH/2016/P01 & $23.11^{d} \pm 0.18$ & Round Oval & Black & Smooth \\
\hline NH/2016/P02 & $18.59^{k} \pm 0.16$ & Round Oval & Brownish black & Smooth \\
\hline NH/2016/P03 & $21.75^{f} \pm 0.15$ & Flat Oval & Black & Smooth \\
\hline NH/2016/P04 & $18.30^{k} \pm 0.32$ & Flat Oval & Black & Wrinkle \\
\hline NH/2016/P05 & $26.11^{a} \pm 0.21$ & Round Oval & Black & Smooth \\
\hline NH/2016/P06 & $23.38^{d} \pm 0.10$ & Flat Oval & Brownish black & Smooth \\
\hline NH/2016/P07 & $19.44^{i} \pm 0.14$ & Round Oval & Black & Smooth \\
\hline NH/2016/P08 & $20.87^{g} \pm 0.19$ & Round Oval & Black & Rough \\
\hline NH/2016/P09 & $17.93^{l} \pm 0.23$ & Round Oval & Brownish black & Smooth \\
\hline $\mathrm{NH} / 2016 / \mathrm{P} 10$ & $18.54^{k} \pm 0.13$ & Round Oval & Black & Smooth \\
\hline $\mathrm{NH} / 2016 / \mathrm{P} 11$ & $21.46^{f} \pm 0.06$ & Round Oval & Black & Smooth \\
\hline NH/2016/P12 & $20.32^{h} \pm 0.26$ & Round Oval & Black & Rough \\
\hline $\mathrm{NH} / 2016 / \mathrm{P} 13$ & $23.74^{c} \pm 0.23$ & Round Oval & Black & Rough \\
\hline $\mathrm{NH} / 2016 / \mathrm{P} 14$ & $19.00^{j} \pm 0.12$ & Flat Oval & Brownish black & Rough \\
\hline $\mathrm{NH} / 2016 / \mathrm{P} 15$ & $24.59^{b} \pm 0.11$ & Flat Oval & Brown & Smooth \\
\hline $\mathrm{NH} / 2016 / \mathrm{P} 16$ & $22.48^{e} \pm 0.13$ & Flat Oval & Brownish black & Smooth \\
\hline
\end{tabular}

The number of clearly visible protein bands ranged from eight to nine among the sixteen accessions of $P$. biglobosa with molecular weights ranging from 11 to $130 \mathrm{kDa}$. Two major clusters of bands were observed between $11-17 \mathrm{kDa}$ and $34-53 \mathrm{kDa}$ and one minor band was observed above $130 \mathrm{kDa}$ (Figure 4). This is similar to results of Adesoye and Apo (2015) on albumin and globulin fractions of $P$. biglobosa in which two major bands were observed at the 16 and $50 \mathrm{kDa}$ regions.

It has been suggested that high molecular weight proteins facilitate the development of seed hardness (Coelho et al, 2007); therefore, the presence of a high molecular weight band observed above the $130 \mathrm{kDa}$ in this study may account for the seed hardness of $P$. biglobosa. The seeds of $P$. biglobosa are very hard and require treatment with sulphuric acid to induce germination.

A polymorphic polypeptide with molecular weight of approximately $24 \mathrm{kDa}$ was absent in NH/2016/P04 but present in all other accessions (Figure 4A) and can be used for its identification. Differences in the presence or absence of bands among accessions are indicative of differences in the genes controlling the different polypeptide subunits (Osanyinpeju and Odeigah, 1998). Also, the presence or absence of polypeptide bands has been found to be linked to the expression of certain characteristics such as wrinkled seeds and insect resistance (Rao and Pernolett, 1981; Odeigah and Osanyinpeju, 1996). The seed shape of NH/2016/P04 was observed to be wrinkled and the absence of the $24 \mathrm{kDa}$ band in this accession may be responsible for this seed texture as it was the only accession expressing this characteristic. Seed storage proteins are non-enzymatic and have the sole purpose of providing proteins (nitrogen and sulphur source) required during germination and establishment of a new plant (Hameed et al, 2012). Legume seed storage proteins are mostly $7 \mathrm{~S}$ and 11S globulins, which tend to be deficient in sulphur-containing amino acids (Tang and Sun, 2010). In mung bean, SDS-PAGE revealed that $11 \mathrm{~S}$ globulin was composed of two bands: $40 \mathrm{kDa}$ and 24 $\mathrm{kDa}, 8 \mathrm{~S}$ vicilin was composed of $60 \mathrm{kDa}, 48 \mathrm{kDa}, 32$ $\mathrm{kDa}$ and $26 \mathrm{kDa}$ bands; and basic 7S globulin was composed of $28 \mathrm{kDa}, 17 \mathrm{kDa}$ and $16 \mathrm{kDa}$ bands (Hameed et al, 2012; Mendoza et al, 2001).

In this study, peptides with molecular weights of 40 $\mathrm{kDa}$ and $24 \mathrm{kDa}$ were detected that may correspond to $11 \mathrm{~S}$ globulin, peptides with molecular weights of $48 \mathrm{kDa}$ and $32 \mathrm{kDa}$ were detected that may correspond to the $8 \mathrm{~S}$ vicilin subunit, while $28 \mathrm{kDa}$ and $16 \mathrm{kDa}$ peptides were also detected that may correspond to the $7 \mathrm{~S}$ globulin subunit. Barakat (2004) reported low levels of protein polymorphism among six cultivars of soybean in which five major bands were identified at the 72, 36, 32, 20 and $16 \mathrm{kDa}$ regions.

In African yam bean, SDS-PAGE separated identical globulin, albumin and vicilin patterns for all 26 accessions studied (Machuka, 2001). Strelec et al (2012) reported that barley varieties could be partially discriminated by albumin/globulin banding patterns using SDS-PAGE, whereas this was not possible with native PAGE which showed more or less identical protein patterns for all varieties.

Through the use of SDS-PAGE on total proteins it is possible to detect a useful band polymorphism to explore the diversity of $P$. biglobosa as was detected in this study, albeit at a low level.

\section{Cluster analysis}

A dendrogram was constructed based on protein banding patterns using Jaccard's similarity coefficients 
(Table 4). The dendrogram grouped the sixteen accessions into four clusters at 0.93 similarity coefficient (Figure 5). The first cluster grouped together the largest number (thirteen) of accessions which consisted of NH/2016/P01, NH/2016/P02, NH/2016/P05, $\mathrm{NH} / 2016 / \mathrm{P} 16, \quad \mathrm{NH} / 2016 / \mathrm{P} 15, \quad \mathrm{NH} / 2016 / \mathrm{P} 06$, $\mathrm{NH} / 2016 / \mathrm{P} 13, \quad \mathrm{NH} / 2016 / \mathrm{P} 12, \quad \mathrm{NH} / 2016 / \mathrm{P} 11$, $\mathrm{NH} / 2016 / \mathrm{P} 10, \mathrm{NH} / 2016 / \mathrm{P} 09, \quad \mathrm{NH} / 2016 / \mathrm{P} 08$ and $\mathrm{NH} / 2016 / \mathrm{P} 07$. The majority of the members of this cluster had similarity coefficient of 1.00 suggesting them to be genetically identical. Cluster II consisted of NH/2016/P14. Accession NH/2016/P03, which was collected in Minna, Niger state and belonging to the Guinea
Savanna agroecological zone, was separated alone into Cluster III, displaying pattern of geographic origin. Cluster IV consisted of $\mathrm{NH} / 2016 / \mathrm{P0} 4$ and was the most divergent of the sixteen tested accessions. The genetic similarity coefficient was 0.85 among NH/2016/P03, $\mathrm{NH} / 2016 / \mathrm{P0} 4$ and NH/2016/P14. Clustering showed pattern of geographic origin as eleven of the thirteen accessions grouped in Cluster I were collected from the Derived Savanna agro-ecological zone.

Genetic distance values give some idea of the level of genetic variability among selected species or accessions. The variation in genetic diversity among the sixteen $P$. biglobosa accessions ranged from 0.85

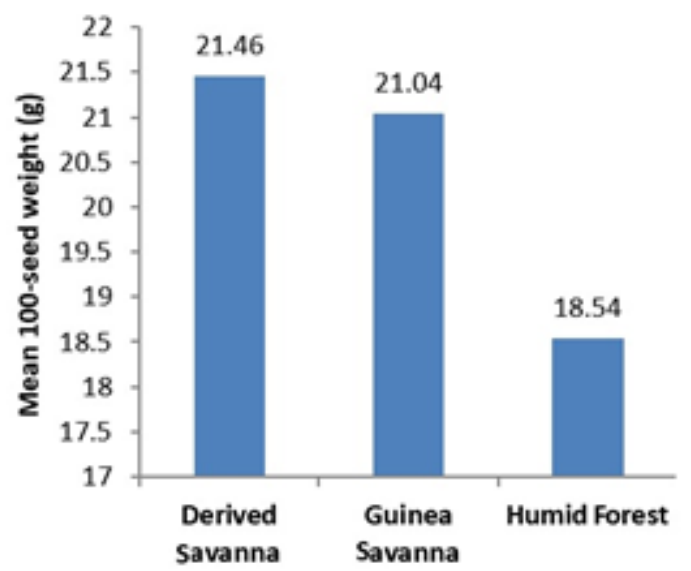

A

Agro-ecological zone

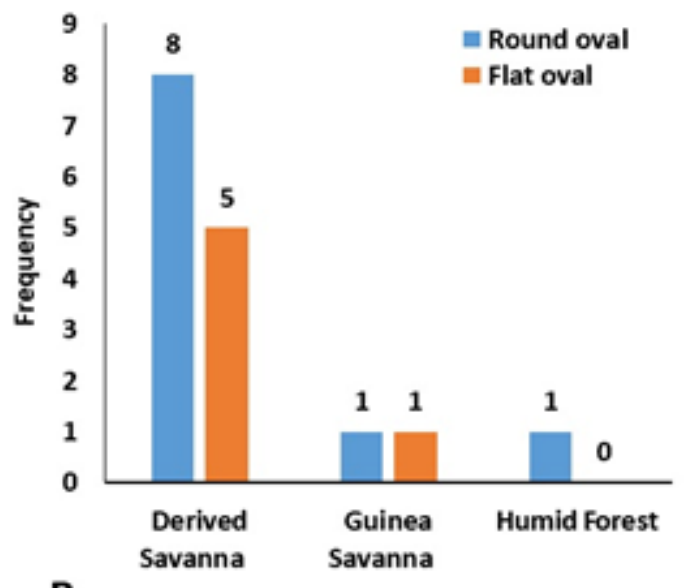

B

Agro-ecological zone

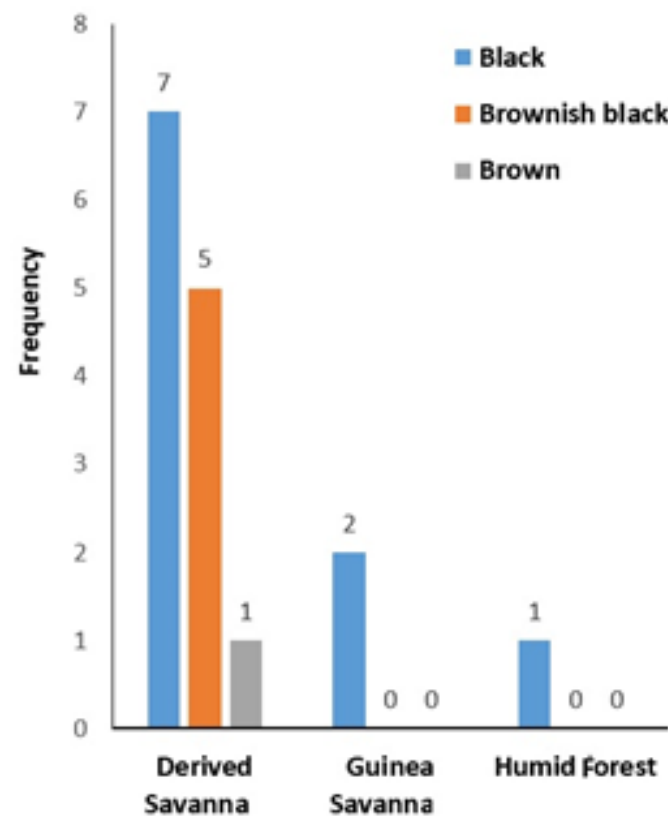

C Agro-ecological zone

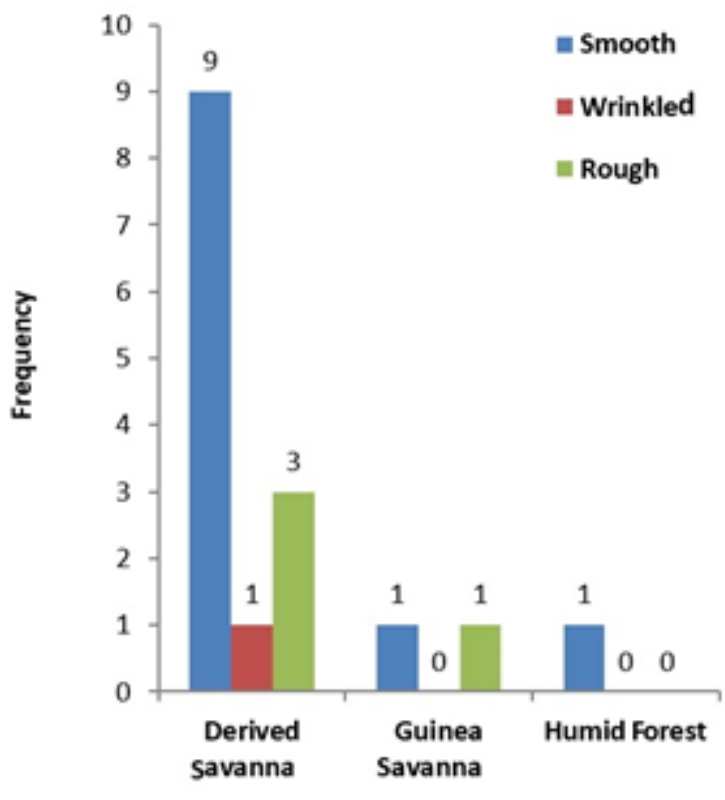

D Agro-ecological zone

Figure 2. Distribution frequencies of seed characteristics of Parkia biglobosa across agro-ecological zones. A) 100-seed weight (g); B) Seed shape; C) Seedcolour; D) Seed coat texture. 

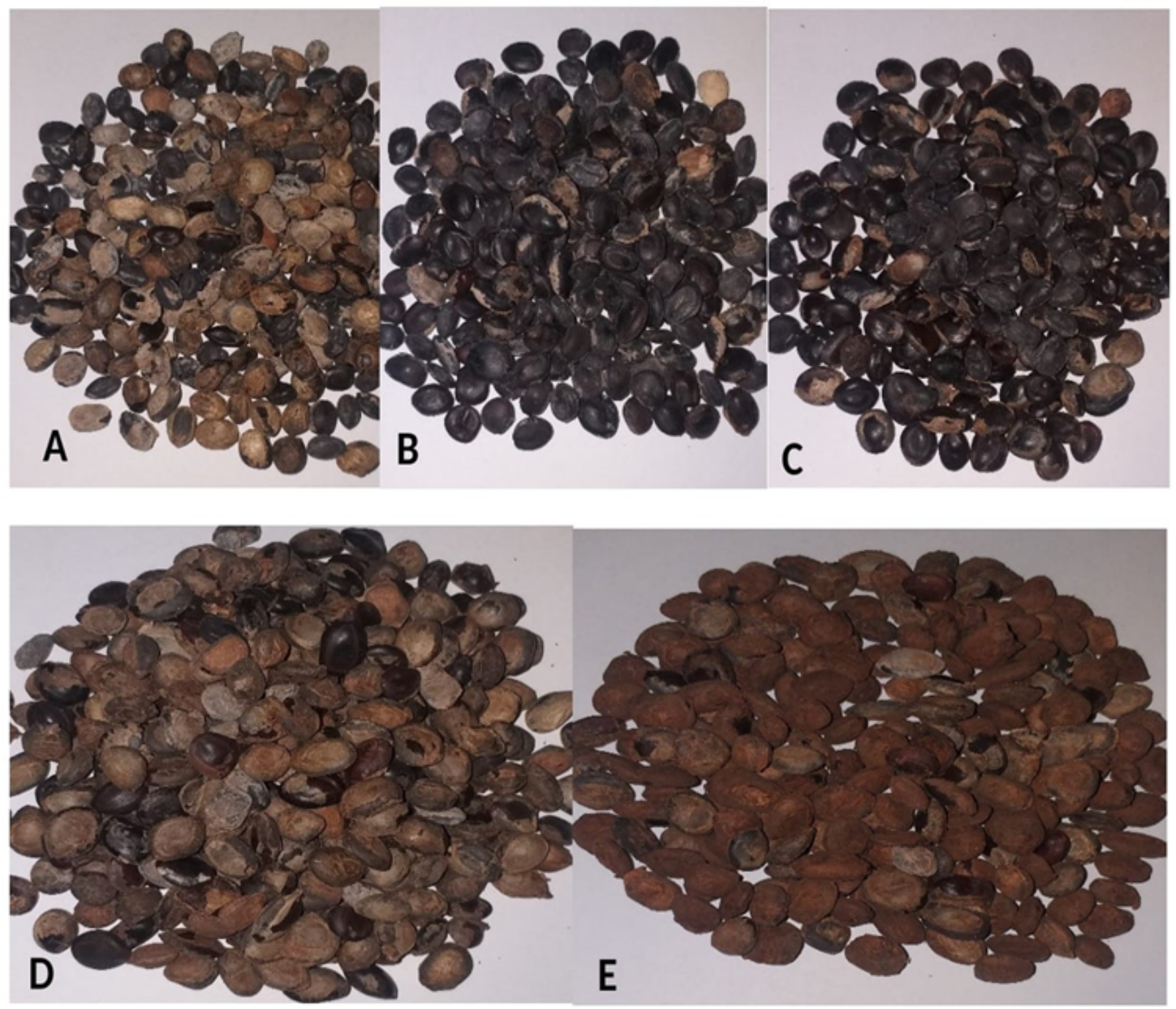

Figure 3. Shapes and colour of seeds with seed coat of Parkia biglobosa: A) Round oval shape (NH/2016/P02), B) Flat oval shape (NH/2016/P03), C) Black colour (NH/2016/P12), D) Brownish black colour (NH/2016/P14), E) Brown colour (NH/2016/P15).

to 0.92 depicting a low genetic diversity (Table 4). All accessions in Cluster I had a similarity coefficient of 0.92 in any pairwise comparisons with $\mathrm{NH} / 2016 / \mathrm{P} 03$, NH/2016/P04 and NH/2016/P14. The low levels of variability observed in P. biglobosa is congruent with Sina (2006) who reported that the genetic distances among P. biglobosa trees in Burkina Faso were low (between 0 and 0.240), indicating that the populations were similar enough to belong to the same genetic group. Occurrence of a narrow genetic base from the accessions of $P$. biglobosa suggests that they may have resulted from a common gene pool and that fixation of variants through genetic drift has probably occurred.

Amusa et al (2014) had earlier reported that close natural populations like $P$. biglobosa exhibited high genetic similarity and low genetic distance attributed to a high rate of exchange of gene flow between populations. Low genetic diversity was also observed in mung bean germplasm based on electrophoresis of seed storage proteins where a dendrogram analysis grouped the tested genotypes into three clusters at 93\% homology (Hameed et al, 2012). Results of this study is similar to that obtained in cowpea in which seven landraces were separated into different clusters based on their geographical origin (Alghamdi et al, 2019). The high level of similarity in the accessions of $P$. biglobosa suggests that the seed storage proteins are highly conserved.

\section{RAPD polymorphism}

Genetic polymorphism is an indication of evolutionary adaptation, which has a main role in the survival of species in a changing environment (Stevens et al, 2007). In this study, Random Amplified Polymorphic DNA (RAPD) amplification profiles revealed a total of 
Table 4. Jaccard's similarity coefficients of seed total protein profiles of Parkia biglobosa accessions.

\begin{tabular}{|c|c|c|c|c|c|c|c|c|c|c|c|c|c|c|c|c|}
\hline & P01 & P02 & P03 & P04 & P05 & P06 & P07 & P08 & P09 & $\mathrm{P} 10$ & $\mathrm{P} 11$ & P12 & P13 & P14 & P15 & P16 \\
\hline P01 & 1.000 & & & & & & & & & & & & & & & \\
\hline P02 & 1.000 & 1.000 & & & & & & & & & & & & & & \\
\hline P03 & 0.923 & 0.923 & 1.000 & & & & & & & & & & & & & \\
\hline P04 & 0.923 & 0.923 & 0.846 & 1.000 & & & & & & & & & & & & \\
\hline P05 & 1.000 & 1.000 & 0.923 & 0.923 & 1.000 & & & & & & & & & & & \\
\hline P06 & 1.000 & 1.000 & 0.923 & 0.923 & 1.000 & 1.000 & & & & & & & & & & \\
\hline P07 & 1.000 & 1.000 & 0.923 & 0.923 & 1.000 & 1.000 & 1.000 & & & & & & & & & \\
\hline P08 & 1.000 & 1.000 & 0.923 & 0.923 & 1.000 & 1.000 & 1.000 & 1.000 & & & & & & & & \\
\hline P09 & 1.000 & 1.000 & 0.923 & 0.923 & 1.000 & 1.000 & 1.000 & 1.000 & 1.000 & & & & & & & \\
\hline P10 & 1.000 & 1.000 & 0.923 & 0.923 & 1.000 & 1.000 & 1.000 & 1.000 & 1.000 & 1.000 & & & & & & \\
\hline P11 & 1.000 & 1.000 & 0.923 & 0.923 & 1.000 & 1.000 & 1.000 & 1.000 & 1.000 & 1.000 & 1.000 & & & & & \\
\hline P12 & 1.000 & 1.000 & 0.923 & 0.923 & 1.000 & 1.000 & 1.000 & 1.000 & 1.000 & 1.000 & 1.000 & 1.000 & & & & \\
\hline P13 & 1.000 & 1.000 & 0.923 & 0.923 & 1.000 & 1.000 & 1.000 & 1.000 & 1.000 & 1.000 & 1.000 & 1.000 & 1.000 & & & \\
\hline P14 & 0.923 & 0.923 & 0.846 & 0.846 & 0.923 & 0.923 & 0.923 & 0.923 & 0.923 & 0.923 & 0.923 & 0.923 & 0.923 & 1.000 & & \\
\hline P15 & 1.000 & 1.000 & 0.923 & 0.923 & 1.000 & 1.000 & 1.000 & 1.000 & 1.000 & 1.000 & 1.000 & 1.000 & 1.000 & 0.923 & 1.000 & \\
\hline P16 & 1.000 & 1.000 & 0.923 & 0.923 & 1.000 & 1.000 & 1.000 & 1.000 & 1.000 & 1.000 & 1.000 & 1.000 & 1.000 & 0.923 & 1.000 & 1.000 \\
\hline
\end{tabular}

256 alleles out of which 163 were polymorphic showing $63.67 \%$ polymorphism among the studied accessions. This relatively high polymorphism suggests a significant amount of genetic diversity among the accessions. A similar result was obtained among 11 soybean cultivars
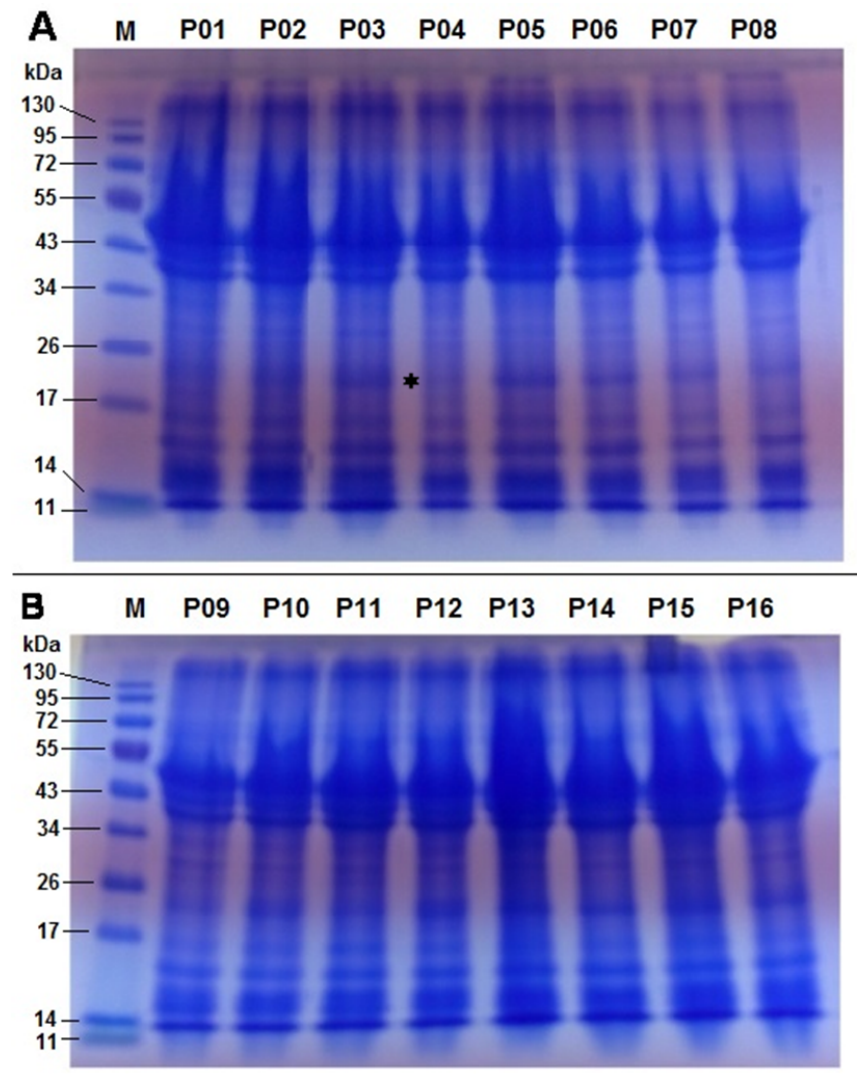

Figure 4. SDS-PAGE of $P$. biglobosa seed total proteins. A) Accessions NH/2016/P01 to NH/2016/08; B) Accessions $\mathrm{NH} / 2016 / \mathrm{P} 09$ to NH/2016/P16. M stands for protein size marker. * indicates the missing $24 \mathrm{kDa}$ band in NH/2016/P04. in which RAPD amplification profiles revealed 61.7\% polymorphism using five primers (El-Kholy, 2013).

Alleles, ranging in size from 250 to 1500 basepairs (bp) and above, were scored for estimation of genetic relationship among the sixteen $P$. biglobosa accessions (Figure 6). An average of 10 alleles per primer was obtained in this study ranging from a minimum of four alleles using primer OPT05 to a maximum of 15 alleles using primer OPB10 (Table 2).

Genetic diversity is one of the important indices for the evaluation of genetic diversity among crop species (Narzary et al, 2009; Tamboli et al, 2016). The genetic diversity in this study ranged from 0.41 to 0.93 , suggesting a significant amount of variation among the 16 accessions evaluated (Table 2). An earlier report on genetic diversity assessment of 23 accessions of $P$. biglobosa from different agro-ecological zones using RAPD indicated weak genetic diversity (expected heterozygosity, $\mathrm{H}_{E}=0.05-0.18$ and observed number of alleles, ONA = 1.11-1.65) (Amusa et al, 2014). The significance of the polymorphic information content

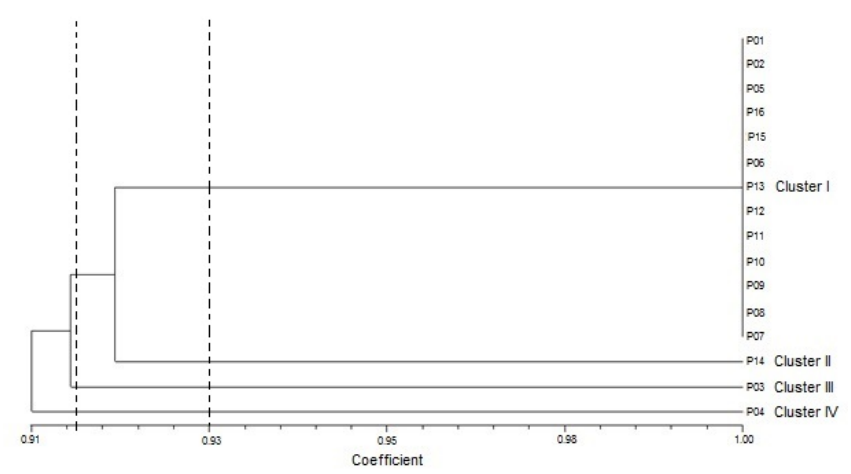

Figure 5. UPGMA dendrogram based on Jaccard's similarity of seed total protein profiles showing close relationship among Parkia biglobosa accessions. 
(PIC) value is such that they are used to evaluate the amount of genetic diversity and are categorized as high (PIC > 0.05), medium (PIC < 0.05) and low (PIC < 0.25) (Abedian et al, 2012). Polymorphic information content ranged from 0.39 for primer OPT05 to 0.93 for primer OPB10 (Table 2).

Fifteen of the sixteen polymorphic primers had PIC values greater than 0.5 indicating that RAPD can develop high-locus polymorphism, which is useful to assess genetic variability of the accessions. All primers showed an average PIC value of 0.79 and nine out of the sixteen primers exceeded the average. This relatively high polymorphism has been observed in studies of genetic diversity on soybean cultivars by Chowdhury et al (2001) and Barakat (2004).

Cluster analysis based on UPGMA revealed six distinct clusters at a genetic similarity coefficient of 0.68 on the UPGMA dendrogram (Figure 7). Cluster I consisted of accessions NH/2016/P01, NH/2016/P05, $\mathrm{NH} / 2016 / \mathrm{P} 12, \quad \mathrm{NH} / 2016 / \mathrm{P} 13, \quad \mathrm{NH} / 2016 / \mathrm{P} 04$, $\mathrm{NH} / 2016 / \mathrm{P} 02, \quad \mathrm{NH} / 2016 / \mathrm{P} 09, \quad \mathrm{NH} / 2016 / \mathrm{P} 14$ and $\mathrm{NH} / 2016 / \mathrm{P} 15$. All the accessions grouped together in Cluster 1 were collected from Derived Savanna except accession NH/2016/P12 which was collected from Guinea Savanna. This suggests that gene flow between the different locations may have occurred as a result of movement of germplasm and exchange of genetic material among farmers and markets. Cluster II consisted of NH/2016/P06; Cluster III consisted of NH/2016/P07 while Cluster IV consisted of NH/2016/P03. Accessions NH/2016/P08, NH/2016/P16 and NH/2016/P11 grouping together in Cluster $\mathrm{V}$ were collected from Derived Savanna. Accession NH/2016/P10 collected from Ogoja, Cross River State in the Humid Forest zone grouped alone in Cluster VI. Thus, in the UPGMA analysis of the RAPD profiles, accessions from same agroecological zone grouped together, while in other cases they were placed in different clusters. For most accessions in this study there was similar clustering pattern of geographically closer accessions, indicating significant association between genetic similarity and geographical distance. This does not agree with a report of Adesoye et al (2013) who reported that distribution of $P$. biglobosa genotypes among clusters did not correspond with their geographical patterns. The lowest similarity was recorded between $\mathrm{NH} / 2016 / \mathrm{P} 10$ and NH/2016/P06, $\mathrm{NH} / 2016 / \mathrm{P} 07, \mathrm{NH} / 2016 / \mathrm{P} 03$. The highest similarity was recorded between accessions NH/2016/P12 and $\mathrm{NH} / 2016 / \mathrm{P} 13$, followed by accessions NH/2016/P05 and both $\mathrm{NH} / 2016 / \mathrm{P} 12, \mathrm{NH} / 2016 / \mathrm{P} 13$. Accessions $\mathrm{NH} / 2016 / \mathrm{P0} 5$ and NH/2016/P13 with narrow genetic distance were collected from the same agro-ecological zone (Derived Savanna). This result corroborates findings of Hamrick and Godt (1989) in which species with small geographic ranges maintained less genetic diversity than geographically widespread species. RAPD clearly distinguished some accessions by accession specific fragments (Figure 6). Therefore, RAPD markers can successfully be used to produce variety specific finger- prints in $P$. biglobosa accessions and are a valuable tool for assessing genetic diversity.

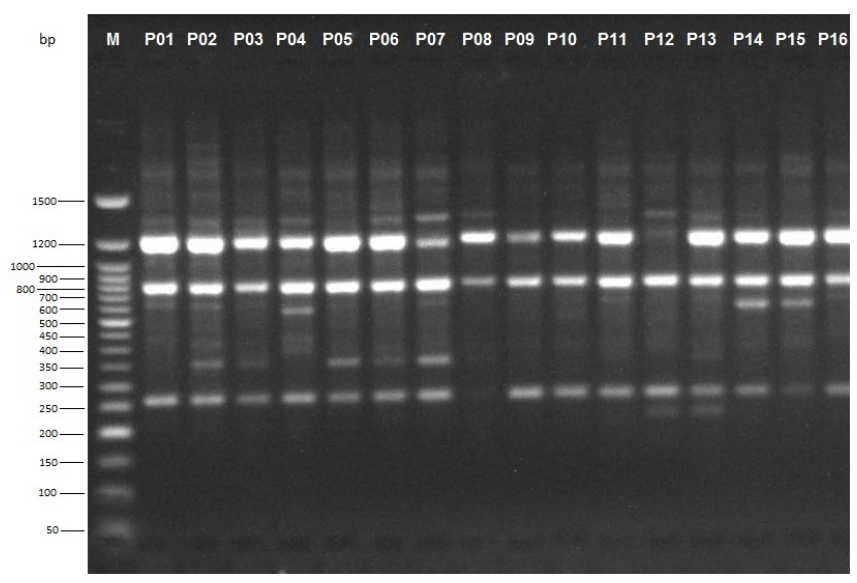

Figure 6. RAPD-PCR analysis of Parkia biglobosa accessions as revealed by primer OPB10. Accessions are numbered as in Table $1 . \mathrm{M}$ is the molecular size marker.

\section{Conclusion}

The low level of variation observed among the accessions as revealed by SDS-PAGE limits the method's applicability to distinguish accessions. Nevertheless, SDS-PAGE was able to detect a polymorphic polypeptide with molecular weight of approximately $24 \mathrm{kDa}$ which was present in all accessions but absent in NH/2016/P04. Thus, SDS-PAGE may not be used to identify accessions based on intraspecific variation;

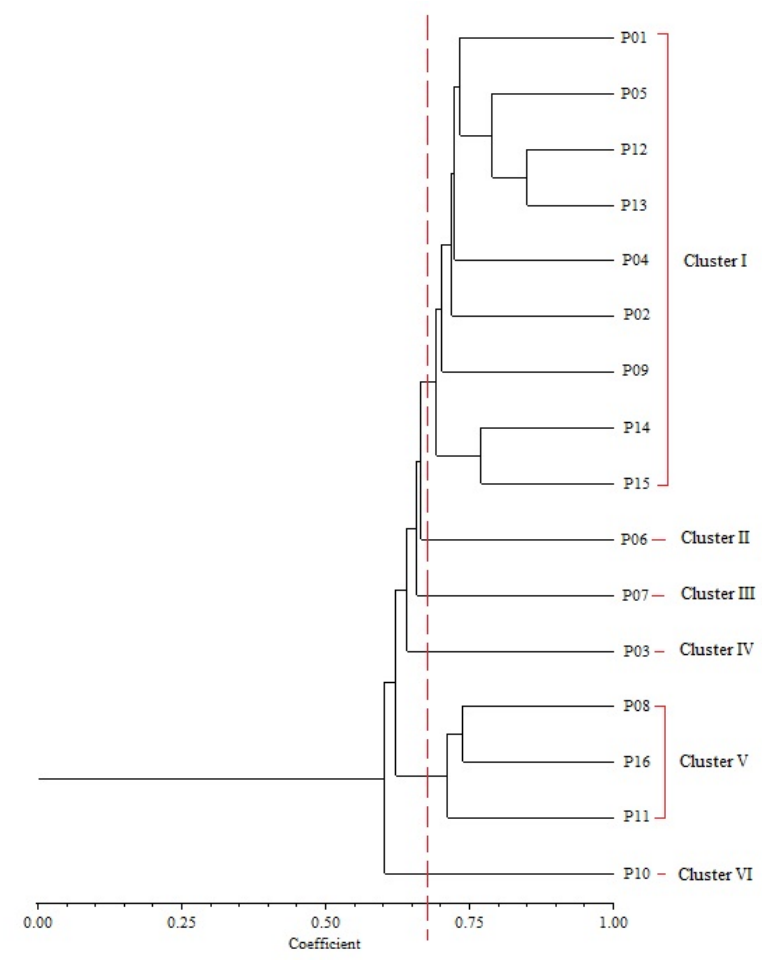

Figure 7. UPGMA dendrogram based on RAPD analysis of Parkia biglobosa accessions. 
rather it might be more suitable to identify interspecific variation.

RAPD-PCR markers were more informative and could be used to discriminate between $P$. biglobosa accessions. Four RAPD primers (OPB10, OPT07, OPB04, OPT12) revealed high degrees of polymorphism among the accessions. The identification of accessions with maximum genetic divergence should be optimized in breeding programmes. The RAPD marker is therefore a more efficient tool to discriminate between accessions of P. biglobosa.

\section{Implications of findings to the conservation and sustainable use of Parkia biglobosa genetic resources}

- The variation observed in qualitative traits and 100 -seed weight among the sixteen accessions of $P$. biglobosa across the three agro-ecological zones of Nigeria indicates their potential for domestication through selection towards conservation and breeding.

- Cluster analysis of the seed protein profile identified NH/2016/P04 as genetically distinct as it was clustered alone and was the most divergent of the sixteen tested accessions. The absence of the 24kDa band in accession NH/2016/P04 distinguishes it from all the other accessions. It can be adopted as parental line for heterosis crossing and should be exploited for conservation, breeding and sustainable utilization.

- Four selected RAPD primers (OPB10, OPT07, OPB04 and OPT12) can be used to discriminate the accessions of $P$. biglobosa.

- The highly diversified accessions of P. biglobosa indicate potential for domestication through selection in breeding programmes.

- Most accessions from the same agroecological zone clustered together suggesting that there is a strong correlation between genetic similarity and geographic proximity.

- The homogeneity of alleles among the studied P. biglobosa accessions suggests possible loss of intraspecific genetic diversity. The weakening gene pool and diversity observed can be enhanced through more germplasm collections, particularly from the diverse agroecological zones of Nigeria for better genetic characterization using more specific markers towards conservation, breeding and sustainable utilization.

\section{Acknowledgements}

Authors are grateful to the Virology Unit of the International Institute of Tropical Agriculture (IITA) Ibadan, Nigeria, for providing the facilities to carry out the SDS-PAGE analysis.

\section{Author contributions}

P. E. Akin-Idowu designed the experiment. P. E. AkinIdowu, A. O. Aduloju and O. I. Akinyoola executed the experiment. O. I. Akinyoola , P. E. Akin-Idowu and D. O. Ibitoye performed the analysis. P. E. Akin-Idowu, O. I. Akinyoola, U. G. Adebo, U. Orkpeh, Y. O. Olagunju and D. O. Ibitoye wrote the manuscript. All the authors read and approved its submission.

\section{Conflict of interest statement}

The authors declare no conflict of interest.

\section{References}

Abedian, M., Talebi, M., Golmohammdi, H. R., and Sayed-Tabatabaei, B. E. (2012). Genetic diversity and population structure of mahaleb cherry (Prunus mahaleb L.) and sweet cherry (Prunus avium L.) using SRAP markers. Biochemical Systematics and Ecology 40, 112-117. doi: https://doi.org/10.1016/j. bse.2011.10.005

Adesoye, A. I. and Apo, K. A. (2015). Evaluating genetic biodiversity of Parkia biglobosa (Jacq.) R. Br. Ex Don (African locust bean) accessions from Nigeria using seed protein electrophoresis. Journal of Crop Science and Biotechnology 18(3), 171-180. doi: https://doi. org/10.1007/s12892-014-0119-9

Adesoye, A. I., Ogunremi, C. O., and Aina, O. O. (2013). Genetic variation and heritability of seedling traits in Africa locust bean Parkia biglobosa (Jacq.) R. Br. ex G. Don. Legume Research 36, 976-0571.

Akin-Idowu, P. E., Egbekunle, K. O., Akinyemi, S. O. S., and Orkpeh, U. (2018). Characterization of the seed proteins of African locust bean (Parkia biglobosa), African breadfruit (Treculia africana) and soybean (Glycine max). Acta Horticulturae 1225(1225), 419426. doi: https://doi.org/10.17660/actahortic.2018. 1225.59

Alabi, D. A., Akinsulire, O. R., and Sanyaolu, M. A. (2005). Qualitative determination of chemical and nutritional composition of Parkia biglobosa (Jacq.) Benth. Afri J Biotechnology 4(8), 812-815.

Alghamdi, S. S., Khan, M. A., Migdadi, H. M., El-Harty, E. H., Afzal, M., and Farooq, M. (2019). Biochemical and molecular characterization of cowpea landraces using seed storage proteins and SRAP marker patterns. Saudi Journal of Biological Sciences 26(1), 74-82. doi: https://doi.org/10.1016/j.sjbs.2018.09. 004

Amusa, O., Adesoye, A., Ogunkanmi, A., Omoche, O., Olowe, O., Akinyosoye, S., and Omodele, T. (2014). Genetic Diversity of Parkia biglobosa from Different Agroecological Zones of Nigeria Using RAPD Markers. International Journal of Biodiversity 2014, 1-6. doi: https://doi.org/10.1155/2014/457309

Awodoyin, R. O., Olubode, O. S., Ogbu, J. U., Balogun, R. B., Nwawuisi, J. U., and Orji, K. O. (2015). Indigenous Fruit Trees of Tropical Africa: Status, Opportunity for Development and Biodiversity 
Management. Agricultural Sciences 06(01), 31-41. doi: https://doi.org/10.4236/as.2015.61004

Badr, A. (2008). Molecular approaches in plant systematics and evolution. Taeckholmia 28, 127-167.

Badr, A., El-Shazly, H. H., Helail, N. S., and Ghanim, W. E. (2012). Genetic diversity of Artemisia populations in central and north Saudi Arabia based on morphological variation and RAPD polymorphism. Plant Systematics and Evolution 298(5), 871-886. doi: https://doi.org/10.1007/s00606-012-0597-5

Barakat, H. (2004). Genetic Fingerprinting and Relationships of Six Soybeans (Glycine max L.) Cultivars Based on Protein and DNA Polymorphism. Int. J. Agri. Biol 6(5), 877-883.

Baránek, M., Kadlec, M., Raddová, J., Vachůn, M., and Pidra, M. (2002). Evaluation of Genetic Diversity in 19 Glycine max (L.) Merr. accessions included in the Czech National Collection of Soybean Genotypes. Czech J Genet Plant Breed 38(2), 69-69. doi: http: //doi.org/10.17221/6114-CJGPB

Boffa, J. M. (1999). Agroforestry parklands in subSaharan Africa volume 34. (Rome: FAO), 1-230. url: http://www.fao.org/3/x3940e/X3940E00.htm.

Chowdhury, A. K., Srinives, P., Tongpmnak, P., and Saksoong, P. (2001). Genetic diversity based on morphology and RAPD analysis in vegetable soybean. Korea J. Crop Sci 46(2), 112-120.

Coelho, C. M. M., Bellato, C. M., Santos, J. C. P., Ortega, E. M. M., and Tsai, S. M. (2007). Effect of phytate and storage conditions on the development of the "hard-tocook' phenomenon in common beans. J Sci Food Agric 87(7), 1237-1243. doi: https://doi.org/10.1002/jsfa. 2822

de la Rosa, A. P. B., Gueguen, J., Paredes-Lopez, O., and Viroben, G. (1992). Fractionation procedures, electrophoretic characterization, and amino acid composition of amaranth seed proteins. Journal of Agricultural and Food Chemistry 40(6), 931-936. doi: https://doi.org/10.1021/jf00018a002

de Xaxars, G. M., Garnatje, T., Pellicer, J., Siljak-Yakovlev, S., Vallès, J., and Garcia, S. (2016). Impact of dysploidy and polyploidy on the diversification of high mountain Artemisia (Asteraceae) and allies. Alpine Botany 126(1), 35-48. doi: https://doi.org/10.1007/ s00035-015-0159-x

Dedehou, V., Olounlade, P., Alowanou, G., Azando, E., and Adote, S. H. (2016). A review on medicinal plants of Parkia biglobosa (MimosaceaeFabaceae) and Pterocarpus erinaceus (LeguminosaePapilionoidea). J. Med. Plants Stud. 4, 132-137.

Dellaporta, S. L., Wood, J., and Hicks, J. B. (1983). A plant DNA minipreparation: Version II. Plant Molecular Biology Reporter 1(4), 19-21. doi: https: //doi.org/10.1007/bf02712670

Dobes, C., Steccari, I., Kostenberger, S., and Lompo, D. (2019). Relative genome size variation in the African agroforestry tree Parkia biglobosa (Fabaceae: Caesalpinioideae) and its relation to geography, population genetics, and morphology. Genome
62(10), 665-676. doi: https://doi.org/10.1139/gen2019-0069

Durán, L. A., Blair, M. W., Giraldo, M. C., Macchiavelli, R., Prophete, E., Nin, J. C., and Beaver, J. S. (2005). Morphological and Molecular Characterization of Common Bean Landraces and Cultivars from the Caribbean. Crop Science 45(4), 1320-1328. doi: https: //doi.org/10.2135/cropsci2004.0501

El-Kholy, A. S. (2013). Evaluation of genetic variation among Soybean (Glycine max L.) Cultivars using SDSPAGE and RAPD Markers. In and others, Egyptian Journal of Botany 3rd International Conference, 3348.

Emre, I. (2009). Electrophoretic analysis of some Lathyrus L. species based on seed storage proteins. Genetic Resources and Crop Evolution 56(1), 31-38. doi: https://doi.org/10.1007/s10722-008-9339-5

Ferreira, E. M. (2006). Molecular analysis of gene banks for sustainable conservation and increased use of crop genetic resources. In The role of biotechnology in exploring and protecting agricultural genetic resources, ed. J., R. and A., S., (Rome, Italy: FAO), 121-128.

Gbadamosi, A. E., Faboye, O. O., and Oni, O. O. (2005). Seed morphological traits, germination and early seedling growth of Parkia biglobosa (Jacq.) R. Br. Ex G. Don. from four provenances in Nigeria. Nigerian Journal of Forestry 35, 129-137.

Hameed, A., Qureshi, M., Nawaz, M., and Iqbal, N. (2012). Comparative seed storage protein profiling of Mungbean genotypes. Pakistan Journal of Botany 44(6), 1993-1999.

Hamrick, J. L. and Godt, M. J. W. (1989). Allozyme diversity in plants. In Plant Population Genetics, Breeding and Genetic Resources, ed. Brown, D. A. H., Clegg, M. T., Kahler, A. L., and Weir, B. S., (Sunderland, Mass, USA: Sinauer), 43-63.

Hopkins, B. (1983). The taxonomy, reproductive biology and economic potential of Parkia (Leguminosae: Mimosoideae) in Africa and Madagascar. Botanical Journal of the Linnean Society 87(2), 135167. doi: https://doi.org/10.1111/j.1095-8339.1983. tb00987.x

Hoque, M. E. and Hasan, M. M. (2012). Molecular Diversity Analysis of Lentil (Lens culinaris Medik.) through RAPD Markers. Plant Tissue Culture and Biotechnology 22(1), 51-58. doi: https://doi.org/10. 3329/ptcb.v22i1.11260

Houndonougbo, J. S. H., Kassa, B., Mensah, S., Salako, V. K., Kakaï, R. G., and Assogbadjo, A. E. (2020). A global systematic review on conservation nd domestication of Parkia biglobosa (Jacq.) R. Br. ex G. Don, an indigenous fruit tree species in Sub-Sahara African traditional parklands: current knowledge and future directions. Genetic Resources and Crop Evolution 67(4), 1051-1066. doi: https://doi.org/10. 1007/s10722-020-00892-w

Jaccard, P. (1908). Nouvelles researches sur la distribution florale. Bulletin de la Societe vaudoise des sciences naturelles 44, 223-270. 
Javaid, A., Ghafoor, A., and Anwar, R. (2004). Seed storage protein electrophoresis in groundnut for evaluating genetic diversity. Pakistan Journal of Botany 36(1), 25-29.

Krochko, J. E. and Bewley, J. D. (2000). Seed storage proteins in cultivars and subspecies of alfalfa (Medicago sativa L.). Seed Science Research 10(4), 423-434. doi: https://doi.org/10.1017/s0960258500000477

Kwon-Ndung, E. H., Chup, C. D., Binbol, N. A., and Ismaila, A. (2009). Ecological implications of climate change on the genetic diversity and distribution of African locust bean Parkia biglobosa in Central Nigeria. IOP Conference Series: Earth and Environmental Science 6(37), 372026-372026. doi: https://doi.org/10.1088/1755-1307/6/37/372026

la Rosa, L. D. and González, J. M. (2010). The genetic diversity associated with seed proteins in a collection of Spanish underground vetches (Vicia sativa L. subsp. amphicarpa (Dorthes) Asch. et Graebn.). Genetic Resources and Crop Evolution 57(4), 565-573. doi: https://doi.org/10.1007/s10722-009-9494-3

Laemmli, U. K. (1970). Cleavage of Structural Proteins during the Assembly of the Head of Bacteriophage T4. Nature 227(5259), 680-685. doi: https://doi.org/10. 1038/227680a0

Lamien, N., Ekué, M., Ouedraogo, M., and Loo, J. (2011). African locust bean (Parkia biglobosa). Conservation and sustainable use of genetic resources of priority food tree species in sub-Saharan Africa. url: http://hdl.handle.net/10532/1681.

Lassen, K. M. (2016). Pollination strategies to increase productivity of the African fruit trees Vitellaria paradoxa subsp. paradoxa \& Parkia biglobosa. Ph.D. thesis, University of Copenhagen, Denmark.

Lassen, K. M., Ræbild, A., Hansen, H., Brødsgaard, C. J., and Eriksen, E. N. (2012). Bats and bees are pollinating Parkia biglobosa in The Gambia. Agroforestry Systems 85(3), 465-475. doi: https://doi. org/10.1007/s10457-011-9409-0

Leakey, R. R. (2012). Living with the trees of life: towards the transformation of tropical agriculture (Wallingford, UK: CABI).

Leakey, R. R. B. (2017). Tree Domestication in Agroforestry: Progress in the 2nd Decade (20032012). In Multifunctional Agriculture. Achieving Sustainable Development in Africa, 139-153.

Lin, K. H., Lai, Y. C., Li, H. C., Lo, S. F., Chen, L. F., and Lo, H. F. (2009). Genetic variation and its relationship to root weight in the sweet potato as revealed by RAPD analysis. Scientia Horticulturae 120(1), 2-7. doi: https://doi.org/10.1016/j.scienta.2008.09.008

Lompo, D., Kanrad, H., Duminil, J., Gaisberger, H., Vincent, B., Quedraogo, M., and Geburek, T. (2016). Genetic diversity of Parkia biglobosa (African locust bean) and its implications for conservation strategies. In Tropentag 2016: Solidarity in a competing world fair use of resources, 18-21 Sep 2016, Vienna, Austria.

Lompo, D., Vinceti, B., Gaisberger, H., Konrad, H., Duminil, J., Ouedraogo, M., Sina, S., and Geburek,
T. (2017). Genetic conservation in Parkia biglobosa (Fabaceae: Mimosoideae) - what do we know? Silvae Genetica 66(1), 1-8. doi: https://doi.org/10.1515/sg2017-0001

Lompo, D., Vinceti, B., Konrad, H., Gaisberger, H., and Geburek, T. (2018). Phylogeography of African Locust Bean (Parkia biglobosa) Reveals Genetic Divergence and Spatially Structured Populations in West and Central Africa. Journal of Heredity 109(7), 811-824. doi: https://doi.org/10.1093/jhered/esy047

Machuka, J. (2001). Heterogeneity in the seed globulin and albumin fractions from African yam bean Sphenostylis stenocarpa (Hoechst. Ex A. Rich) harms. African Crop Science Journal 9(4), 607-613. doi: https: //doi.org/10.4314/acsj.v9i4.27583

Malik, M. F. A., Qureshi, A. S., Ashraf, M., Khan, M. R., and Javed, A. (2009). Evaluation of genetic diversity in soybean (Glycine max) lines using seed protein electrophoresis. Australian Journal of Crop Science 3(2), 107-112.

Matig, O. E., Gaoué, O. G., and Dossou, B. (2002). Réseau «Espèces Ligneuses Alimentaires». In Compterendu de la première réunion du Réseau tenue 11-13 décembre 2000 au CNSF , 235-235.

Mendoza, E. M. T., Adachi, M., Bernardo, A. E. N., and Utsumi, S. (2001). Mungbean [Vigna radiata(L.) Wilczek] Globulins: Purification and Characterization. Journal of Agricultural and Food Chemistry 49(3), 1552-1558. doi: https://doi.org/10.1021/jf001041h

Mondini, L., Noorani, A., and Pagnotta, M. (2009). Assessing Plant Genetic Diversity by Molecular Tools. Diversity 1(1), 19-35. doi: https://doi.org/10.3390/ d1010019

Murray, B. G. (2005). When does Intraspecific C-value Variation become Taxonomically Significant? Annals of Botany 95(1), 119-125. doi: https://doi.org/10. 1093/aob/mci007

Mustafa, A. M. A. and El-Kholy, A. S. (2008). Genetic diversity among some accessions of Vicia faba $\mathrm{L}$. around the world. In Proceedings of 5th International Conference of Biological Science (Botany) 5, 10-10.

Narzary, D., Mahar, K. S., Rana, T. S., and Ranade, S. A. (2009). Analysis of genetic diversity among wild pomegranates in Western Himalayas, using PCR methods. Scientia Horticulturae 121(2), 237-242. doi: https://doi.org/10.1016/j.scienta.2009.01.035

Nei, M. (1987). Molecular evolutionary genetics (New York: Columbia University Press).

Nei, M. and Li, W. H. (1979). Mathematical model for studying genetic variation in terms of restriction endonucleases. Proceedings of the National Academy of Sciences 76(10), 5269-5273. doi: https://doi.org/10. 1073/pnas.76.10.5269

Nikiema, A. (2005). Agroforestry parkland species diversity: uses and management in semi-arid West Africa (Burkina Faso). Ph.D. thesis, Wageningen University, Wageningen, the Netherlands.

Nyadanu, D., Amoah, R. A., Obeng, B., Kwarteng, A. O., Akromah, R., Aboagye, L. M., and Adu- 
Dapaah, H. (2017). Ethnobotany and analysis of food components of African locust bean (Parkia biglobosa (Jacq.) Benth.) in the transitional zone of Ghana: implications for domestication, conservation and breeding of improved varieties. Genetic Resources and Crop Evolution 64(6), 1231-1240. doi: https:// doi.org/10.1007/s10722-016-0432-x

Odeigah, P. G. C. and Osanyinpeju, A. O. (1996). Seed protein electrophoretic characterization of cowpea (Vigna unguiculata) germplasm from IITA gene bank. Genetic Resources and Crop Evolution 43(6), 485-491. doi: https://doi.org/10.1007/bf00138825

Okoye, T. G., Uzor, P. F., Onyeto, C. A., and Okereke, E. K. (2014). Safe African Medicinal Plants for Clinical Studies. In Toxicological Survey of African Medicinal Plants, 535-555.

Okunlola, A. I., Adebayo, R. A., and Orimogunje, A. D. (2011). Methods of breaking seed dormancy in germination and early seedling growth of African locust bean Parkia biglobosa (Jacq.) Benth. . Journal of Horticulture and Forestry 3(1), 1-6.

Oni, P. I., Hall, J. B., and Ladipo, D. O. (1998). The ecology of a key African multipurpose tree species, Parkia biglobosa (Jacq.) Benth: the current state of knowledge. Nigerian Journal of Ecology 1, 59-77.

Orwa, C., Mutua, A., Kindt, R., Jamnadass, R., and Anthony, S. (2010). Agroforestree Database: a tree reference and selection guide version 4.0. CD-ROM.

Osanyinpeju, A. O. and Odeigah, P. G. C. (1998). Variation in seed proteins from mutagen-treated cultivars and selected lines of Vigna unguiculata L. Walp. Plant Breeding 117(4), 361-365. doi: https: //doi.org/10.1111/j.1439-0523.1998.tb01954.x

Ouedraogo, A. S. (1995). Parkia biglobosa (Leguminosae) en Afrique de l'Ouest : biosystematique et amelioration. Ph.D. thesis, Wageningen University, Wageningen, Netherlands. (in French).

Padakale, E., Atakpama, W., Dourma, M., Dimobe, K., Wala, K., Guelly, K., and Akpagana, K. (2015). Woody Species Diversity and Structure of Parkia biglobosa Jacq. Dong Parklands in the Sudanian Zone of Togo (West Africa). Annual Research \& Review in Biology 6(2), 103-114. doi: https://doi.org/10.9734/arrb/ 2015/14105

Prasanthi, L., Geetha, B., Ramyajyothi, B. N., and Reddy, K. (2012). Evaluation of genetic diversity in cowpea, Vigna unguiculata (L.) Walp genotypes using random amplified polymorphic DNA (RAPD). Current Biotica 6(1), 22-31.

Przybylska, J., Zimniak-Przybylska, Z., and Krajewski, P. (2000). Diversity of seed globulins in Lathyrus sativus $\mathrm{L}$ and some related species. Genetic Resources and Crop Evolution 47(3), 239-246. doi: https://doi.org/ 10.1023/A:1008750423357

Ræbild, A., Hansen, U. B., and Kambou, S. (2012a). Regeneration of Vitellaria paradoxa and Parkia biglobosa in a Parkland in Southern Burkina Faso. Agroforestry Systems 85, 443-453. doi: https://doi. org/10.1007/s10457-011-9397-0
Ræbild, A., Hansen, U. B., and Kambou, S. (2012b). Regeneration of Vitellaria paradoxa and Parkia biglobosa in a parkland in Southern Burkina Faso. Agroforestry Systems 85(3), 443-453. doi: https://doi. org/10.1007/s10457-011-9397-0

Rao, R. and Pernolett, J. C. (1981). Pisum sativum seed globulin as biochemical markers for wrinkled smooth seed character: comparison of genotypes through different protein extraction and electrophoretic procedures. Agronomie 1(10), 909-916.

Rohlf, F. J. (2002). NTSYS-PC Numerical taxonomy and multivariate analysis system.

Sammour, R. H., Mustafa, A., Badr, S., and Tahr, W. (2007a). Genetic variations in accessions of Lathyrus sativus. L. Acta Botanical Croatica 66(1), 1-13.

Sammour, R. H., Radwan, S. A., and El-Kholy, A. (2007b). Genetic variability in Phaseolus spp. as revealed by SDS-PAGE Markers. Seed technology 29(1), 50-59.

Sankhon, A., Amadou, I., Yao, W. R., Wang, H., Qian, H., and Sangare, M. (2014). Comparison Of Physicochemical And Functional Properties Of Flour And Starch Extract In Different Methods From Africa Locust Bean (Parkia biglobosa) Seeds. African Journal of Traditional, Complementary and Alternative Medicines 11(2), 264-264. doi: https:// doi.org/10.4314/ajtcam.v11i2.6

Shao, M. (2002). Parkia biglobosa: Changes in resource allocation in Kandiga, Ghana. Ph.D. thesis, Michigan Technological University, Houghton, MI, USA.

Signor, C. L., Gallardo, K., Prosperi, J. M., Salon, C., Quillien, L., Thompson, R., and Duc, G. (2005). Genetic diversity for seed protein composition in Medicago truncatula. Plant Genetic Resources 3(1), 59-71. doi: https://doi.org/10.1079/pgr200562

Sina, S. (2006). Reproduction et diversite genetique chez Parkia biglobosa (Jacq) G. Don. Ph.D. thesis, Wageningen University, Wageningen, the Netherlands.

Sina, S. and Traore, S. A. (2002). Parkia biglobosa (Jacq.) R. Br. ex G. Don. In PROTA (Plant Resources of Tropical Africa/Ressources végétales de l'Afrique tropicale), ed. Oyen, L. P. A. and Lemmens, R. H. M. J., (Wageningen, Netherlands) .

Stevens, L., Salomon, B., and Sun, G. (2007). Microsatellite variability and heterozygote excess in Elymus trachycaulus populations from British Columbia in Canada. Biochemical Systematics and Ecology 35(11), 725-736. doi: https://doi.org/10. 1016/j.bse.2007.05.017

Strelec, I., Has-Schon, E., and Vitale, L. (2012). Comparative electrophoretic patterns of albumins/globulins from dry grains and green malts of barley varieties. Poljoprivreda 18(2), 36-43. url: https://hrcak.srce.hr/ 94628.

Tamboli, A. S., Patil, S. M., Gholave, A. R., Kadam, S. K., Kotibhaskar, S. V., Yadav, S. R., and Govindwar, S. P. (2016). Phylogenetic analysis, genetic diversity and relationships between the recently segregated species of Corynandra and Cleoserrata from the genus Cleome 
using DNA barcoding and molecular markers. Comptes Rendus Biologies 339(3-4), 123-132. doi: https://doi. org/10.1016/j.crvi.2016.02.005

Tang, C. H. and Sun, X. (2010). Physicochemical and Structural Properties of 8S and/or 11S Globulins from Mungbean [Vigna radiate (L.) Wilczek] with various polypeptide constituents. J. Agric. Food Chem 58(10), 6395-6402. doi: https://doi.org/10.1021/jf904254f

Teklehaimanot, Z. (2004). Exploiting the potential of indigenous agro forestry trees: Parkia biglobosa and Vitellaria paradoxa in Sub-Sahara Africa. In New Vistas in Agroforestry, Springer, Dordrecht, Netherlands, 207-220.

Uyoh, E. A., Urua, I. S., Ntui, V. O., and Okpako, E. C. (2011). Flow cytometry analysis of nuclear DNA content, mitotic chromosome number and protein separation by SDS-PAGE in three accessions of African locust bean (Parkia biglobosa Benth.). Journal of Crop Science and Biotechnology 14(4), 227-232. doi: https://doi.org/10.1007/s12892-011-0043-1

Wang, A., Zhang, P., Liu, X., Liang, J., and Li, W. (2016). Genetic structure and diversity of Glehnia littoralis, an endangered medicinal plant in China. Biochem Syst Ecol 66, 265-271. doi: https://doi.org/10.1016/j.bse. 2016.04.019

Zarkadas, C. G., Gagnon, C., Gleddie, S., Khanizadeh, S., Cober, E. R., and Guillemette, R. J. (2007). Assessment of the protein quality of fourteen soybean [Glycine max (L.) Merr.] cultivars using amino acid analysis and two-dimensional electrophoresis. Food Research International 40(1), 129-146. doi: https:// doi.org/10.1016/j.foodres.2006.08.006 